\title{
Toward Non-innocent Reassemblies
}

\author{
A Commentary on Dana Simmons' "Imposter Syndrome, A Reparative History"
}

\author{
MiCHELLE MURPHY \\ UNIVERSITY OF TORONTO
}

\begin{abstract}
This commentary explores the toggle between reparative and paranoid reading that the Simmon's essay performs, drawing connections to feminist STS and Fanon.
\end{abstract}

\section{Keywords}

method; reparative reading; non-innocent reassemblies; Fanon

What might a reparative approach in STS look like? Dana Simmons' essay enters into this question through the feelings and historicity of Imposter Syndrome as a pervasive gendered and raced angst enflamed by an individualized "achievement" culture in the United States, offering up a methodological challenge that is at once about politics and ethics (Simmons 2016). Simmons, a historian of science, has all the methodological chops to historicize and deconstruct Imposter Syndrome as an artifact of capitalism, sexism, racism, and the liberal subject. Yet, what would such an analysis do in the world? Who would feel better, or differently? Would it cure readers of their own feelings of anxiety and imposture?

Drawing on Eve Kosofsky Sedgwick's influential work (Sedgwick 2002), Simmons describes this historicizing mode as a kind of paranoid reading, and following a path of analysis developed in queer psychyoanalytic theory, her approach takes up Sedgwick's invitation to a reparative analysis. Moving beyond the application of reparative reading onto Imposter Syndrome, however, the essay goes on to rethink the very method of reparative reading - how it too is webbed within similar formations of the therapeutic cure of the individual academic. Tacking between historicization / critique and reparative modes, Simmons' essay pulls us over to an unexpected place: repair studies in STS, through the work of Steve Jackson (2014) and hence towards the question of preserving or changing already broken worlds, and not only anxious

‘ Michelle Murphy, Email: michele.murphy@utoronto.ca

Copyright (C) 2016 (Michelle Murphy). Licensed under the Creative Commons Attribution Non-commercial No Derivatives (by-nc-nd). Available at estsjournal.org. 
subjects. The essay eschews an instrumental mode to either reparative reading or repair studies, and instead draws on the important legacy of feminist theorizations of situated knowledge and the new turn from objects of concern to "objects of care" in feminist STS. Crucial to recent feminist STS conversations on care is the insistence on not giving up critique in favor of merely following positive feeling as a guide. Positive feeling can just as much be about fitting in easily and smoothing hegemonic relationships of the status quo, as it is about reaching for less violent worlds in research practices. Here, Imposter Syndrome becomes an important prompt, drawing Simmons back to dwelling with, and not just dismissing, negative affect. Is the paranoid read, so wrong? Or, as I read Simmons' suggestion, perhaps the reparative read needs the paranoid read if it is not just to fall into a curative politics of the individual. Critique and repair toggle uneasily together. The critical reparative goal here is not a subject who smoothly and confidently exists in the high achievement world. Rather, the essay calls out Imposter Syndrome for the complicity it performs with achievement culture, and with the God's eye trick of mastery. There is no curative solution at the level of the subject that might fix the pernicious psychic effects of neoliberal academia: the future of precarious labor for both graduate and undergraduate students alike, the practices of audit on productivity, the hostility to critical humanities and social science research, the cuts to programs in the name of austerity, and so much more.

I want to suggest, then, that what gets "repaired" in this essay is not so much Imposter Syndrome, as it is reparative reading itself. Reparative reading is metamorphosed into reassembly, and crucially, non-innocent reassembly. Here, Simmons crafts a feminist STS method of critical tinkering, not merely with concepts like Imposter Syndrome, but importantly with the very formations that gave rise to Imposter Syndrome. In Simmons' word's

The Reassembled Impostor tinkers with the mechanisms of evaluation and achievement to make them more just and livable. She considers the instruments of evaluation, tools used on and by her, as social affective technologies. She is cognizant of the speeds of modernization, entrepreneurship and career advancement, and manipulates these speeds by inserting place-holders and stop-gaps with whatever materials are at hand. She seeks to foster other kinds of differential subjectivity (Sandoval 2000). She celebrates spaces of anti-achievement, of failure, play and exploration (Halberstam 2011). She is responsible for shared histories of injustice and works where she can to make amends for past exclusions. She reassembles achievement worlds.

While mere historicization cannot deflate the experience of Imposter Syndrome, through its toggle between affect and critique, between historicization and reparation, the essay performs a deflation of Imposter Syndrome in its analysis: what matters now is not so much undermining the diagnosis, as disrupting the structural and affective conditions in which so many people feel like there is no place for them in the livable world, that their subjectivities are inadequate for academia. And, put even more starkly: disrupting the structures that actively create hostile, unbearable conditions for not just study, but life. Here we are together, reading this essay, studying in the cruelties of neoliberal academia. This is a quite different place from, "Am I an imposter? Do I have imposter syndrome?" 
Simmons essay and approach to Imposter Syndrome in many ways reminds me of one of Frantz Fanon's most read essays, "The Fact of Blackness," which in fact is a poor translation of its original French title, "L'expérience vécue du Noir," and hence is better translated as "The Lived Experience of the Black."= The essay is part of the book Black Skin, White Masks (Fanon 1994), a text originally written as Fanon's dissertation, rejected as inappropriate, and then published to become one of the most important texts ever written about decolonization. There is so much for STS to learn from Fanon, but here I will pull out one particular observation that resonates with Simmons' essay. Fanon was a practicing psychiatrist, and his writing grapples both with the possibilities and complicities of science, and with the affective and phenomonelogical dimensions of existence, which also included, for Fanon, being a doctor and a researcher. In this famous essay, Fanon is agonizing over the impossibility of being a black subject in a white world of French colonial academia and science that is consistently hostile to his humanity. Fanon howls into the ache of theorizing this condition, in which the very act of theorization is also caught up in the philosophies, methods, and ontologies of the world that seeks to negate his being, that posits blackness as the anti-human, or the negation of being itself. Methodologically, Fanon's essay toggles between the necessity and impossibility of his being, the refusal and insistence on thinking black existence amidst the dissonance of its negation and the many projects that celebrate and repair blackness. Fanon rightly condemns the approach of historicizing blackness (here offered up by Sartre) as merely a condition to be undone. Between hope and despair, Fanon ends his brilliant essay, "Yesterday, awakening to the world, I saw the sky turn upon itself utterly and wholly. I wanted to rise, but the disemboweled silence fell back up on me, its wings paralyzed. Without responsibility, straddling Nothingness and Infinity, I began to weep." Fanon shows us how pessimism, fear, anxiety, and anger are politically, ethically, and theoretically generative, even as they are also pernicious effects of being assaulted by endemic racism that saturates intellectual life in the aftermaths of colonialism.

Simmons' article brings this Fanon essay to mind because, although it begins from a very different point of departure (white U.S. femaleness) and with decidedly different stakes, Simmons' essay too draws the reader to the political stakes of their own affective entanglements as a subject in the "high achievement world" of American capitalism, riven as it is with white supremacy and heteropatriarchy-and also as a researcher. The essay reflexively hails us as students and researchers, who by attending to the affective dimension of our experience, might move from the neoliberal model of getting individualized therapy for our mental health towards a reassembly of our conditions of subjectivation in research cultures. Perhaps, like me, mental health at your university is addressed by distributing informational lists of phone numbers to instructors so that you might point students in crisis to under-resourced campus and community services. Or perhaps you have numerous students whose experience with anxiety has led them to seek disability status at the university. Or, as is statistically likely, you are a precarious laborer in academia who is structurally made to feel like the embodiment of failure. At what point does our unevenly shared condition of labor and study as students, instructors, and professors in STS

Fanon $(1994,140)$. 
become part of our "objects of care?" The essay invites us to take responsibility for engaging in collective disruption and the remaking of the very conditions of academic life. Thus, at its most radical, Simmons' essay is not a mere analysis of Imposter Syndrome, but a nuanced call to acknowledge the harmful subjectivations that academia is entangled within, which is also posed as an invitation to interrupt our very conditions of work and assembly. What might these noninnocent reassemblies look like? What experiments in reassembly are already happening? I am excited to partake. I am grateful to Dana Simmons' essay for its generosity and for prompting these thoughts.

\section{References}

F. Fanon. 1994. Black Skin, White Masks. New York: Grove Press.

Halberstam, J. 2011. The Queer Art of Failure. Durham: Duke University Press.

Jackson, S. J. 2014. "Rethinking Repair." In Media Technologies: Essays on Communication, Materiality, and Society, edited by Tarleton Gillespie, Pablo J. Boczkowski, and Kristen Foot, 221-40. Cambridge: MIT Press.

Sedgwick, E. K. 2002. Touching Feeling: Affect, Pedagogy, Performativity. Durham: Duke University Press.

Simmons, D. 2016. "Impostor Syndrome, a Reparative History." Engaging Science, Technology, and Society 2: 106-127. DOI:10.17351/ests2016.33. 